\title{
Known and predicted impacts of the invasive oak lace bug (Corythucha arcuata) in European oak ecosystems - a review
}

\author{
Márton Paulin, Anikó Hirka, Csaba Béla Eötvös, Csaba Gáspár, \\ Ágnes Fürjes-Mikó, György Csóka*
}

Department of Forest Protection, NARIC Forest Research Institute, 3232 Mátrafüred, Hegyalja str. 18., Hungary

\begin{abstract}
Paulin, M., Hirka, A., Eötvös, Cs.B., Gáspár, Cs., FürJes-Mikó, Á., Csóka, Gy., 2020. Known and predicted impacts of the invasive oak lace bug (Corythucha arcuata) in European oak ecosystems - a review. Folia Oecologica, 47 (2): 131-139.

The North American oak lace bug (OLB, Corythucha arcuata) was first found in Europe in northern Italy in 2000, and up to 2019 it was recorded in 20 countries. Almost all Eurasian deciduous oak species are suitable hosts and the species can also feed on many other woody plants. At least 30 million hectares of oak forests provide suitable hosts for the OLB, meaning that the lack of suitable hosts will not restrict its further spread. Detailed studies on the long-term impact of the species are not yet available but there are many good reasons to assume that it poses multiple threats to oaks and oak ecosystems. In the long term, it may have negative effects on oak health, growth, and acorn crops. Many of other oak-associated species will likely also be negatively affected. So far, no effective and environmentally tolerable large scale control method is known for OLB.
\end{abstract}

Keywords

Corythucha arcuata, invasive species, leaf discoloration, oaks, spreading

\section{Introduction}

Non-native insect species have appeared at an alarmingly increasing rate worldwide and also in Europe in recent decades (RoQues, 2010; Kenis and Branco, 2010; Tuba et al., 2012; SMITH et al., 2018). More new non-native insects feeding on woody plants were recorded in Hungary during the last three decades than in the previous 110 years (CsóKA et al., 2012). While some non-native insects spread slowly and do not cause detectable economic/ecological damage, others become invasive, rapidly expand their range and subsequently have rather severe effects in their newly invaded area, causing severe economic and ecological damage. The oak lace bug (Corythucha arcuata Say,
1832 - Heteroptera: Tingidae; abbreviated to OLB hereafter) is a recent example of a fast-spreading non-native insect with significant damage potential in its newly invaded range. In this paper, we briefly summarize the most important knowledge available on OLB and highlight the knowledge gaps for this species. Identifying these gaps may help determine necessary directions for further OLB research in Europe.

\section{A brief summary of the origin, biology and European spread of OLB}

OLB is native to the Eastern USA as far north as Southern Canada. The adult bugs overwinter in bark crevices or

*Corresponding author: e-mail: csokagy@erti.hu 
under raised bark. It has 2 or even 3 generations per year (CONNELl and BEACHER, 1947; CSEPELÉNYI et al., 2017a). The females lay their eggs in groups of 10-100 on the underside of oak leaves. Both nymphs and adults feed here by sucking from the lower leaf surface, resulting in separate small (1-3 $\mathrm{mm})$, later increasing and merging greyishyellow spots on the upper leaf surface. Heavy infestation can cause total discoloration of the foliage by the second half of the growing season, sometimes even as early as late June (CSEPELÉNYI et al., 2017a; PAULIN et al., 2020).

Within Europe, OLB was first reported in northern Italy (BERNARDINELLI et al., 2000). Even then, it was predicted that the species might spread through most of
Europe and that range expansion was likely unstoppable. However, very few new country records were reported over the following decade. Explosively rapid spread was only observed more than a decade after the first European record. As OLB is a typical "hitchhiker", its long-distance spread is facilitated by road and rail traffic. With this human-mediated help, it can "jump" long distances within a short time. The stages in its spread within Europe are summarized in Fig 1.

The estimated total forest area infested by OLB in five countries (Croatia, Hungary, Romania, Russia in Europe, and Serbia) exceeded 1.7 million hectares (Table 1) by autumn 2019.

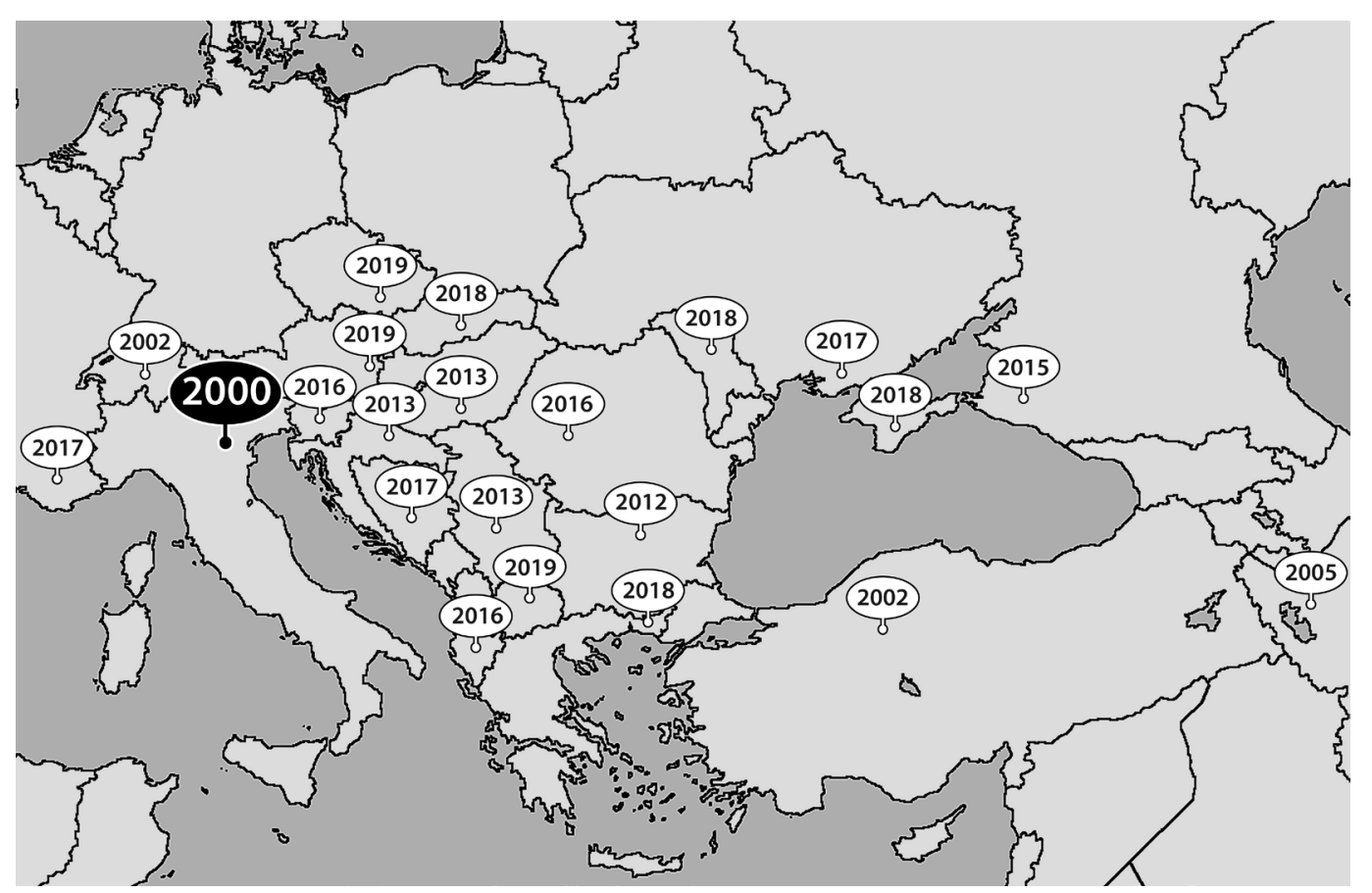

Fig. 1. The European distribution of OLB in 2020, with the year of first record for each country. The map is based on the following reports: Bernardinelli and Zandigiacomo (2000), Mutun (2003), Forster et al. (2005), Dobreva et al. (2013), Csóka et al. (2013), Hrašovec et al. (2013), Don et al. (2016), Neimorovets et al. (2017), Glavendekic (2017), JuRC \& Jurc (2017), Dautbašić et al. (2018), Streito et al. (2018), DerJanschi \& Mocreac (2018), AvtZis (pers. comm.), Zúbrik et al. (2019), SALLMANNSHOFER et al. (2019), MertelíK and LišKa (2020).

Table 1. Estimation of the infested area in five countries in autumn 2019

\begin{tabular}{ccc}
\hline Country & Infested area (ha) & Source \\
\hline Croatia & 300,000 & B. Hrašovec - pers. comm. \\
Hungary & 114,000 & Our own survey \\
Romania & 160,000 & F. Bălăcenoiu - pers. comm. \\
Russia (European part) & $\min 1,000,000$ & Y. Gninenko - pers. comm. \\
Serbia & $\min 180,000$ & M. Glavendekic - pers. comm. \\
Total & $\min 1,754,000$ & - \\
\hline
\end{tabular}




\section{Known and potential hosts of OLB}

The host range of OLB was surveyed in 20 botanical gardens and arboreta in 7 countries (CsóKA et al., 2019). 27 of the 48 oak (Quercus) species checked were found to be suitable hosts, and of these 15 were recorded as new hosts globally. Almost all Eurasian deciduous oaks can be hosts (both in section Quercus and section Cerris). None of the North American red oaks (Section Lobatae) are suitable hosts. This means that at least 30 million hectares of oak forests may become suitable hosts in Europe. In other words, lack of hosts is unlikely to restrict further spread of OLB.

In addition to oak hosts, CsóKA et al. (2019) recorded 29 non-oak host species (Rubus, Corylus, Acer, etc.). The survival rate and fecundity of OLB developing on nonoak hosts are still unknown. According to BERNARDINELLI (2006a), OLB nymphs can develop successfully on Rubus leaves (with less than 30\% mortality). These potential hosts may be important for further spread of OLB.

\section{Climatic limitation of the further spread?}

Climate may also have a very significant influence on the establishment, spread and population dynamics of an alien invasive species. BERNARDINELLI (2006b) made a comparison between the native range (the eastern USA and Canada) and Europe and concluded that most of Europe could be suitable climatically for further spread of the OLB. ZIELINSKA and Lis (2020) discussed the risk of OLB establishment in Poland. They concluded that southern Poland is suitable for OLB both from in terms of climatic conditions and presence/abundance of oak forests. Our field survey on overwintering mortality (CSEPELÉNYI et al., 2017b; PAulin et al., 2019) proved that the overwintering adults suffered $50 \%$ or lower mortality even in relatively cold winters. This suggests that the winter weather is unlikely to restrict further spread to the east, north and west, particularly if we consider the tendency under climate warming towards shorter and milder winters. Natural barriers to dispersal (e.g. the Carpathians, Alps) may slow range expansion, but are unlikely to prevent it in the longer term.

\section{Natural enemies and pathogens}

A number of arthropod native enemies are mentioned from the USA including an unnamed hover fly (CONNELL and BEACHER 1947), two mirid bugs (Hyaliodes vitripennis and Deraeocoris nebulosus) and an anthocorid bug, Orius insidiosus (CONNELL and BEACHER 1947; WHEELER et al., 1975). CONNELL and BEACHER (1947) mentioned several birds (finches, treecreepers and nuthatches) feeding on OLB, particularly on adults.

PUTTLER et al. (2014) found that an egg parasitoid, Erythmelus klopomor Triapitsyn (Hymenoptera, Mymaridae), was the most common and abundant natural enemy of OLB. Its host range is restricted to tingids and it seems to prefer OLB. All its host species overwinter as an adult; therefore it is likely that the parasitoid also overwinters as an adult in bark crevices and under raised bark. PUTTLER et al. (2014) consider this species to be a promising candidate for a classical biological control program against OLB in Europe.

Many native natural enemies (coccinellids, lacewings, predatory bugs, velvet mites, spiders, etc.) have been recorded to feed on some developmental stage of OLB since its discovery in Europe, but none strongly regulate its populations. The situation in Hungary is the same. There are sporadic records of native enemies, but none are significant from the point of regulation. Some generalist predators, such as red wood ants (Formica rufa), avoid OLB, even if infested leaves are placed on the ground near their hills (our own unpublished observation). A hypothetical explanation (not yet proven experimentally) is that some repellent chemicals are present in or on the body of OLB nymphs and adults. Knowledge on natural enemies reported from two invaded European countries (Italy and Hungary) is summarized in Table 2.

SÖNMEZ et al. (2016) tested several entomopathogenic fungi against OLB under laboratory conditions in Turkey. Beauveria bassiana seemed to be the most efficient (both against nymphs and adults), causing $>80 \%$ mortality. Kovač et al. (2020) reported four naturally occurring entomopathogenic fungi (Beauveria pseudobassiana, Lecanicillium pissodis, Akanthomyces attenuatus and Samsoniella alboaurantium) from Croatia, without giving information on prevalence or population impacts of these pathogens. Overwintering OLB adults killed by an unidentified entomopathogenic fungus (likely Beauveria sp.) were found at several locations in Hungary, but the mortality rate these imposed was less than $0.1 \%$ (our own unpublished data).

It is very likely that the explosive spread and outbreaks of OLB in Europe can at least partly be explained by escape from its natural enemies, since in the USA, OLB is much less abundant and is not even considered a significant forest pest.

\section{Known and predicted impacts on oaks and oak ecosys- tems}

The impacts of OLB on oaks and oak ecosystems in its native range are little-known. Only early leaf abscission and general weakening of infested trees (without provision of data) are mentioned (CONNELL and BEACHER, 1947). In its native range it is not considered a significant pest, and therefore no focused research has specifically addressed the damage it causes. But explosive range expansion and extremely high abundance in consecutive years in some recently invaded European countries may suggest high potential risk, both from ecological and economic points of view.

\section{Direct, evident impacts}

Nymphs and adults sucking on the underside of leaves cause small but later expanding and merging spots on the upper leaf surface. These spots often cover the whole leaf surface. When OLB reaches high densities, this discolor- 


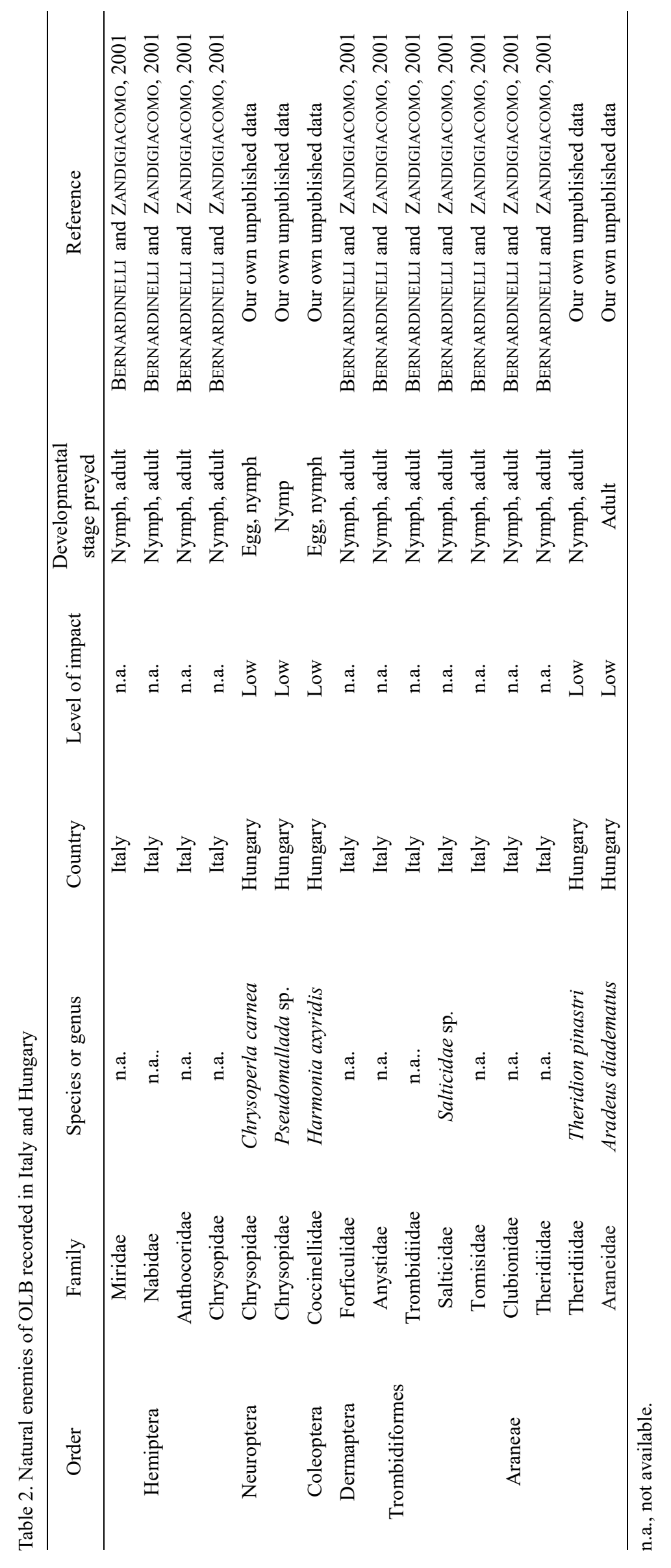


ation can be observed on $100 \%$ of the foliage by late July or August, but sometimes as early as late June. Severely infested leaves dry and fall 1.5-2 months before normal leaf abscission. With a little practice, these symptoms can be recognized even from long distance: drone, aerial and even space images (MODIS, Sentinel, Google Earth, etc.) can help to detect severe infestation. The estimated area of infestation in five countries is shown in Table 1 (autumn 2019).

\section{Physiological impacts}

While tissues on the underside of affected leaves remain relatively intact, the chlorophyll all but disappears from the upper surface tissues of severely infested leaves. This has an important negative effect on photosynthesis since ca. $80 \%$ of this happens in the palisade chlorenchyma of the leaves' upper surface (LAMBERs et al., 1998). According to a recently published Serbian study, photosynthetic activity decreased by $58.8 \%$, transpiration activity decreased by $21.7 \%$, and stomatal conductance decreased by $35.7 \%$ on severely infested leaves (NiKOLIĆ et al., 2019). It is very unlikely that this impact would not have severe long-term impact on the oaks' nutrient and water flow.

\section{Potential impacts on growth}

Insect defoliation of oaks in spring is known significantly reduce radial growth (MuZIKA and LieBHOLD 1999; Colbert and Fekedulegn, 2001). However, hardly any information is known on the effect of defoliation occurring later in the growing season (mid-summer or later). The within-year phenology of oak growth is dependent on many environmental variables. However, it is quite clear that most radial growth in oaks $(Q$. robur, $Q$. petraea, $Q$. cerris) occurs in the first part of the growing season, with $80 \%$ of growth typically completed by late July (SzÖNYI 1962; JÁRó and TÁTRAALJAI, 1984-1985; HiRKA, 19901991). Based on these facts, it can be assumed that damage caused by OLB (if it does not happen extremely early) will not have dramatic effects on within-year radial growth, but the accumulated effect of many years' repeated damage will likely have a significant impact on it.

\section{Potential impacts on oak health}

The health status of oak forests is influenced by many abiotic and biotic factors. Many studies worldwide report that more frequent and severe droughts will significantly reduce the health of forest trees, including oak stands. If these climate predictions are accurate, further declines in forest health can be expected (CsókA 1996, 1997; McManus and CsóKA, 2007; CsóKA et al., 2009, 2015, 2018; KLAPWIJK et al., 2013; BERKI et al., 2018; HiRKA et al., 2018; MáTYÁs et al., 2018). A new invasive insect imposing severe physiological effects on oaks will almost certainly contribute to further deterioration, worsening the prospects for oak forests, particularly if damage is repeated over the long-term. The disturbance in nutrient and water flow will almost certainly increase the stress level and become a significant element of the "damage chain", resulting in oak decline and mass mortality.

Several species of tingid bugs, for example the sycamore lace bug (Corythucha ciliata), are mentioned as potential vectors of a plant pathogen (MiTCHELL, 2004). Though as-yet unproven, it is possible that OLB could act as a vector for leaf pathogens.

\section{Potential impacts on acorn crop}

There are many observations but few scientific records on the connection between the negative effects of oak defoliation and the acorn crop. According to CRAWLEY (1985) even a minor foliage loss $(8-12 \%)$ caused by spring caterpillars can significantly reduce acorn yield.

According to observations in Croatia and Hungary, substantial early acorn abscission and smaller acorn size can be detected in oak stands severely infested by OLB. There were efforts to quantify these observations in Croatia, but so far no significant direct link has been found (Franjevic et al., 2018). The same is true for our own experiments in 2019.

Acorn growth usually accelerates in July during the time when the negative physiological effects caused by OLB intensify. Therefore it is assumed that the physiological effects of OLB on oak foliage have detectable knockon effects on acorn crop. Acorns of Turkey oak (Quercus cerris) develop for two years, meaning that OLB effects will directly influence acorn development for two years.

Another important question is how the cumulative effects of OLB infestation over several years will influence the quantity and quality of the acorn crop. This could have severe practical concerns, since the periodicity and troublesome predictability of acorn yields have already caused and are still causing significant difficulties in forestry. This could escalate to significant decrease or even total loss of the acorn crop, hindering natural regeneration of oak stands or the production of reproductive material in nurseries.

\section{Potential impacts on oak-associated insect species}

Oaks are characteristic and dominant tree species in many natural habitats in Europe and harbor uniquely high diversity of herbivorous insect species (CRAWLEY, 1983). Compared to other tree species, oaks probably support the highest associated species richness. In the UK, oaks support 423 species of herbivore (feeding on living plant tissue: KENNEDY and SouthwOOD, 1984), with corresponding richnesses of 298 species from Germany (AltENKIRCH, 1986) and over 670 species from Hungary (CsóKA and AMBRUs, 2016). Oak-feeding Lepidoptera alone comprise more than 300 species in Hungary (CsóKA and AMBrus, 2016). Most species that feed on oaks are polyphagous, but in Hungary the number of specialist oak-feeding insect species approaches 300 (CsóKA and AmBrus, 2016). MitCHell et al. (2019) mentioned 326 species (57 fungi, 257 invertebrates, 12 lichens) obligately associated with oaks in the UK. It is clear that oaks are keystone species that play an important and irreplaceable role in maintain- 
ing the biodiversity in forested ecosystems. In Hungary, approximately 450 insect species (many of which are rare and protected) feed (chewing, mining, galling, etc.) on oak leaves (CsóKA and AMBrus, 2016). Richness of these species peaks during the first half of the growing season, feeding on younger foliage. Later in the season the potential number of oak-feeding species decreases; during the second half of the growing season, oak feeders are usually dominated by the second generation of bivoltine species and oak specialists (monophagous/oligophagous). However, even later in the season the number of species potentially feeding or developing on the leaves is high, at approximately 180 species in August/September.

This is why we have good reasons to assume that severe infestation by OLB over a large area - which results in premature yellowing and drying of the foliage - will have a serious impact (due to exploitative competition) on the insects developing in the foliage during the second half of the growing season. Heavily infested leaves are unsuitable food sources for many leaf-feeding species in late summer and early autumn. Our preliminary results show that the caterpillars of tawny prominent (Harpya milhauseri), oak marbled brown (Drymonia querna) and some geometrid larvae (i.e. Cyclophora spp.) have all starved and died when only heavily infested leaves are available as food. A similar situation applies for leaf galling gall wasps (Cynipidae). We observed that the galls of Cynips quercusfolii as well as Neuroterus quercusbaccarum and $N$. numismalis were unable to complete their development at all or only with high mortality on severely infested leaves (PAULIN et al., 2019). This effect can be especially drastic if it repeats over several years or becomes chronic. We would expect that severe decline of some herbivorous insect populations could have a significant trophic cascade of negative impacts on their predators and parasites as well.

It is not yet known whether mass infestation of the OLB in a given year has any effect on herbivorous communities in the following spring. It is also not yet known how the long-term (or permanent) negative physiological impacts will influence other oak-associated species (mycorrhizal fungi, litter decomposers, etc.).

\section{Potential impacts on the surface waters}

SAVVIDIS et al. (2009) named sycamore lace bug (Corythucha ciliata) as the causal agent of mass fish mortality in northwest Greece. The faeces and adult bugs were washed into a stream from infested Platanus trees during heavy rains, and these were shown experimentally to cause mass mortality of young farmed trout. There is thus reason to believe that mass abundance of OLB could have similar impacts on fish and aquatic invertebrates living in natural surface waters.

\section{Human-health concerns}

The sycamore lace bug (Corythucha ciliata) occasionally bites and causes painful inflammations on human skin
(Dutto and Bertero, 2013; IzRi et al., 2015). Occasional bites by OLB adults searching for food are reported from Romania (CiCEOI et al., 2018), Hungary (PAulin et al., 2020) and Croatia (Kovač et al., 2020). It is very likely that this kind of human/OLB interaction will become more and more frequent in future if the species' range expands even further and its abundance remains high. This may particularly happen in infested oak forests frequently visited by tourists, but even more likely in parks, on oak alleys in towns and private gardens with planted oaks.

\section{Control options}

Small scale chemical control can only be considered in gardens and parks. Systemic insecticides are most likely the best options, since both larvae and adults are relatively protected on the underside of the leaves. But even in case of a successful chemical control, there is a high risk of reinfestation, so possibly only more than one spraying would guarantee good results.

In large oak forests, chemical control is absolutely not feasible. Firstly, it would be unacceptably expensive, particularly because most probably more than one treatment during a season would be necessary. Even more importantly, this heavy chemical load on oak forests would cause very serious undesired non-target effects.

Successful classical biological control seems to be the only viable option for fighting the OLB in its newly invaded range. But a program like this must be preceded by studies on non-target organisms and a rigorous survey of the potential undesired ecological effects.

\section{Conclusions}

OLB seems to be a potentially very dangerous invasive species both from an ecological and economic point of view. In the long term, it will likely have negative impacts on oak growth, health, acorn crop, and associated rich communities of oak-related organisms (insects, fungi, etc.). However, there are major knowledge gaps concerning the details and complexity of potential OLB impact on oaks and oak ecosystems. Filling these gaps is absolutely vital in justifying the necessity for a classical biological control program.

\section{Acknowledgements}

Our work on OLB is supported by the Ministry of Agriculture and the OTKA 128008 research project sponsored by the National Research, Development and Innovation Office. Many thanks to Professor Graham Stone (Edinburgh University) for his valuable comments and for correcting and improving the English of the manuscript. We are thankful to Ferenc Szentkirályi and Csaba Szinetár for identification of OLB's natural enemies found in Hungary. 


\section{References}

AltenKIRCH, W., 1986. Die Veränderung natürlicher Waldgesellschaften Norddeutschlands und ihre Folgen für den Ökosystem- und Artenschutz aus zoologischer Sicht [The change in natural forest-like forests in Northern Germany and their consequences for ecosystem and species protection from a zoological point of view]. Arbeitsgemeinschaft Foresteinrichtung, Arbeitskreis Zustandserfassung und Planung. Jahrestagung. Luxemburg, 21-23 May 1986. Unpublished brochure, p. 1-17.

Berki, I., Móricz, N. Rasztovits, E. Gulyás, K. Garamszegi, B. Horváth, A. Balázs, P., Lakatos, B., 2018. Fapusztulás és gyorsuló növekedés kocsánytalan tölgyeseinkben [Wood decline and accelerating growth in our sessile oak stands]. Erdészettudományi Közlemények, 8 (1): 119-130.

Bernardinelli, I., 2000. Distribution of the Oak lace bug Corythucha arcuata (Say) in northern Italy (Heteroptera Tingidae). Redia, 83: 157-162.

Bernardinelli, I., 2006a. Potential host plants of Corythucha arcuata (Het., Tingidae) in Europe: a laboratory study. Journal of Applied Entomology, 130: 480-484.

BERNARDINELLI, I., 2006b. European host plants and potential distribution of Corythucha arcuate (Say) (Heteroptera: Tingidae). In CsóKa, Gy., Hirka, A., Koltay, A. (eds). Biotic damage in forests. Proceedings of the IUFRO Symposium (WP 7.03.10 "Methodolgy of forest pest and disease survey in Central Europe") held in Mátrafüred, Hungary, September 12-16, 2004. Budapest: Hungarian Forest Research Institute, p. 10-17.

Bernardinelli, I., Zandigiacomo, P., 2000. Prima segnalozione di Corythucha arcuata (Say) (Heteroptera, Tingidae) in Europa [First record of the oak lace bug Corythucha arcuata (Say) (Heteroptera, Tingidae) in Europe]. Informatore Fitopatologico, 12: 47-49.

Bernardinelli, I., Zandigiacomo, P., 2001. Corythucha arcuata (Say): a new pest for European oaks. In KNIZEK, M., Forster, B., Grodzki, W., Chira, D., Mihalciuc, V., Minalache, G. (eds). Methodology of forest insect and disease survey in Central Europe. Proceedings of the IUFRO working party 7.03.10 workshop. September 2428, 2000, Buşteni, Romania. Braşov, Romania: Ed. Lux Libris, p. 121-122.

Ciceor, R., Radulovici, A., 2018. Facultative blood-sucking lace bugs, Corythucha sp. in Romania. In Anastasiu, P., Trichkova, T., Uludag, A., Tomov, R. (eds). Book of abstracts. Joint ESENIAS and DIAS scientific conference and 8th ESENIAS workshop. Management and sharing of IAS data to support knowledge based decision making at regional level. Bucharest, Romania, 26-28 September 2018. Bucharest, Romania: Editura Universitatii din Bucuresti, p. 90.

Colbert, J.J., Fekedulegn, D., 2001. Effect of gypsy moth defoliation on tree growth - preliminary models for effects of cumulative defoliation on individual host tree radial increment. In Liebhold, A.M., McManus, M.L., Öтvös, I.S., Fosbroke, S.L.C. (eds). Proceedings "Integrated management and dynamics of forest defoliating insects". General Technical Report, 227. Newtown Square, PA: USDA Forest Service, Northeastern Research Station, p. 16-30.
CONNEll, W.A., BeACHER, J.H., 1947. Life history and control of the oak lace bug. Bulletin of the University of Delaware Agricultural Experiment Station, 265. 28 p.

Crawley, M.J., 1983. Herbivory, the dynamics of animalplant interactions. Studies in Ecology, 10. Berkeley: University of California Press. 437 p.

Crawley, M.J., 1985. Reduction of oak fecundity by low-density herbivore populations. Nature, 314: 163-164.

CSEPElÉNYI, M., HiRKA, A., SzÉNÁSI, Á., Mikó, Á., SzŐCS, L., CsóKA, Gy., 2017a. Az inváziós tölgycsipkéspoloska (Corythucha arcuata (Say, 1832)) gyors terjeszkedése és tömeges fellépése Magyarországon [Rapid area expansion and mass occurrences of the invasive oak lace bug (Corythucha arcuata (Say, 1932)) in Hungary]. Erdészettudományi Közlemények, 7: 127-134.

Csepelényi, M., Hirka, A., Mikó, Á., Szalai, Á., Csóka, Gy., 2017b. A tölgy-csipkéspoloska (Corythucha arcuata) 2016/2017-es áttelelése Délkelet-Magyarországon [Overwintering success of the oak lace bug (Corythucha arcuata) in 2016/2017 in south-eastern Hungary]. Növényvédelem, 53: 285-287.

CsóKA, Gy., 1996. Aszályos évek- fokozódó rovarkárok erdeinkben [Years of drought - increasing damage by forest insects]. Növényvédelem, 32: 545-551.

CsóKA, GY., 1997. Increased insect damage in Hungarian forests under drought impact. Biologia, 52, 1-4.

CsókA, Gy., Ambrus, A., 2016. Erdei fa- és cserjefajok szerepe a herbivor rovarok fajgazdagságának fenntartásában [Role of forest woody plants in maintaining species richness of herbivorous insects]. In KORDA, M. (ed.). $A z$ erdögazdálkodás hatása az erdők biológiai sokféleségére. Tanulmánygyüjtemény. Budapest: Duna-Ipoly Nemzeti Park Igazgatóság, p. 155-192.

Csóka, Gy., Hirka, A., Mutun, S., Glavendekic, M., Mikó, Á., Szöcs, L., Paulin, P., Eötvös, Cs.B., Gáspár, Cs., CsepelÉNyi, M., SzÉnÁsi, Á., Franjevic, M., GninenKo, Y., Dautbašic, M., Mujezinovic, O., Zúbrik, M., Netoiu, C., A Buzatu, A., Balacenoiu, F., Jurc, M., Jurc, D., Bernardinelli, I., Streito, J.C., D., Avtzis, D., Hrašovec, B., 2019. Spread and potential host range of the invasive oak lace bug [Corythucha arcuata (Say, 1832) - Heteroptera: Tingidae] in Eurasia. Agricultural and Forest Entomology, 22 (1): 61-74.

Csóka, Gy., Hirka, A., Somlyai, M., 2013. A tölgy-csipkéspoloska (Corythucha arcuata Say, 1832 - Hemiptera, Tingidae) első észlelése Magyarországon [First occurrences of the invasive oak lace bug (Corythucha arcuata (Say, 1932)) in Hungary]. Növényvédelem, 49 (7): 293-296.

CsóKA, GY., HirKA, A., Szöcs, L., 2012. Rovarglobalizáció a magyar erdőkben [Insect globalization in the Hungarian forests]. Erdészettudományi Közlemények, 2: 187-198.

CsóKa, Gy., Hirka, A., Szőcs, L., MóRICz, N., Rasztovits, E., PÖDÖR, Z., 2018. Weather-dependent fluctuations in the abundance of the oak processionary moth, Thaumetopoea processionea (Lepidoptera: Notodontidae). European Journal of Entomology, 115: 249-255. doi: 10.14411/ eje. 2018.024

CsóKa, Gy., Koltay, A., Hirka, A., JaniK, G., 2009. Az aszályosság hatása kocsánytalan tölgyeseink és bükköseink egészségi állapotára [The effect of drought on the health of our sessile oaks and beeches]. Klima-21 Füzetek, 57: 64-73. 
CsókA, Gy., PöDör, Z., NAGy, Gy., Hirka, A., 2015. Canopy recovery of pedunculate oak, Turkey oak and beech trees after severe defoliation by gypsy moth (Lymantria dispar): case study from Western Hungary. Lesnicky Časopis - Forestry Journal, 61: 143-148.

Dautbašić, M., Zahirović, K., Mujezinović, O., Margaletić, J., 2018. First record of oak lace bug (Corythucha arcuata) in Bosnia and Herzegovina. Šumarski List, 142 (3-4): 179-181.

DerJannschi, V., Mocreac, N., 2018. Tigrul stejarului Corythucha arcuata (Say, 1832) (Heteroptera, Tingidae) species noua invzivain fauna Republicii Moldova [Oak lace bug Corythucha arcuata (Say, 1832) (Heteroptera, Tingidae) - new invasive species in the fauna of the Republic of Moldova]. Buletin Ştiinţific. Revistă de Etnografie, Ştiinţele Naturii şi Muzeologie, 28 (41): 30-35.

Dobreva, M., Simov, N., Georgiev, G., Mirchev, P., GeorGIEVA, M., 2013. First record of Corythucha arcuata (Say) (Heteroptera: Tingidae) on the Balkan Peninsula. Acta Zoologica Bulgarica, 65 (3): 409-412.

Don, I., Don, C.D., Sasu, L.R., Vidrean, D., Brad, M.L., 2016. Insect pests on the trees and shrubs from the Macea Botanical garden. Studia Universitatis 'Vasile Goldiş' Arad Seria Ştiinţe Inginereşti şi Agro-Turism, 11 (2): 23-28.

Dutto, M., Bertero, M., 2009. Dermatosis caused by Corythucha ciliata (Say, 1932) (Heteroptera, Tingidae). Diagnostic and clinical aspects of an unrecognized pseudoparasitosis. Journal of Prevenetive Medicine and Hygiene, 54 (1): 57-59.

Forster, B., Giacalone, I., Moretti, M., Dioli, P., WerMELINGER, B., 2005. Die amerikanische Eichennetzwanze Corythucha arcuata (Say) (Heteroptera, Tingidae) hat die Südschweiz erreicht [The American oak lace bug Corythucha arcuata (Say) (Heteroptera, Tingidae) has reached southern Switzerland]. Mitteilungen der Schweizerischen Entomologischen Gesellschaft, 78 (3/4): 317.

Franjević, M., Drvodelić, D., Kolar, A., GradečKIPoŠTenJaK, M., Hrašovec, B., 2018. Impact of oak lace bug Corythucha arcuata (Heteroptera: Tingidae) on pedunculate oak (Quercus robur) seed quality. In RADOJČIĆ Redovniković, I., Jakovljević, T., Petravić Tominac, V., Panić, M., Stojaković, R., Erdec, D., Radošević, K., Gaurina Sarček, V., Cvjetko Bubalo, M. (eds). Natural resources, green technology \& sustainable development - GREEN/3. Zagreb: Faculty of Food Technology and Biotechnology, University of Zagreb, Croatia, p. $161-165$.

GLAVENDEKIĆ, M., 2017. Fauna i ekologija insekata koji naseljavaju invazivne i nativne ukrasne biljke [Fauna and ecology of insects that inhabit invasive and native ornamental plants]. In ObRatov-PetKovic, D. (ed.). Ukrasne i invazivne biljke u uslovima klimatskih promena - uticaji $i$ adaptacije. Monografija. Beograd: Univerzitet u Beogradu-Šumarski fakultet, p. 240-264.

HIRKA, A., 1990-1991. Bükk, luc és kocsánytalan tölgy éves kerületnövekedési menetének vizsgálata [Investigation of the annual circumference growth of beech, spruce and sessile oak]. Erdészeti Kutatások, 82-83: 15-23.

Hirka, A., Pödör, Z., Garamszegi, B., Csóka, Gy., 2018. A magyarországi erdei aszálykárok félévszázados trend- jei [50 years trends in forest drought damage in Hungary (1962-2011)]. Erdészettudományi Közlemények, 8 (1): $11-25$.

Hrašovec, B., Posarić, D., Lukić, I., Pernek, M., 2013. Prvi nalaz hrastove mrežaste stjenice Corythucha arcuata u Hrvatskoj [First record of the oak lace bug Corythucha arcuata in Croatia]. Šumarski List, 9-10: 499-503.

Izri, A., Andriantsoanirina, V., Chosidow, O., Durand, R., 2015. Dermatosis caused by blood-sucking Corythucha ciliata. JAMA Dermatology, 151 (8): 909-910.

JÁRó, Z., Tátraaljai, E-NÉ, 1984-1985. A fák éves növekedése [Annual growth of trees]. Erdészeti Kutatások, 76-77: 221-234.

JURC, M., JURC, D., 2017. The first record and the beginning the spread of Oak lace bug, Corythucha arcuata (Say, 1832) (Heteroptera: Tingidae), in Slovenia. Šumarski List, 141 (9-10): 485-488.

Kenis, M., Branco, M., 2010. Impact of alien terrestrial arthropods in Europe. Chapter 5. In Roques, A., Kenis, M., LEES, D. (eds). Alien terrestrial arthropods of Europe. Vol. 1. BioRisk, 4. Sofia: Pensoft, p. 51-71.

Kennedy, C.E.J., Southwood, T.R.E., 1984. The number of species of insects associated with British trees: a re-analysis. Journal of Animal Ecology, 53: 455-478.

KLAPWiJK, M.J., CsÓKa, Gy., Hirka, A., BJöRKMAN, C., 2013. Forest insects and climate change: long-term trends in herbivore damage. Ecology and Evolution, 3 (12): 41834196.

Kovač, M., Gorczak, M., Wrzosek, M., Tkaczuk, C., PerNEK, M., 2020. Identification of entomopathogenic fungi as 2 naturally occurring enemies of the invasive oak lace bug, Corythucha arcuata (Say) (Hemiptera: Tingidae). Insects, 11: 679 .

Lambers, H., Chapin, III F.S., Pons, T.L., 1998. Physiological plant ecology. New York: Springer. $341 \mathrm{p}$.

Mátyás, Cs., Berki, I., Bidló, A., CsóKA, Gy., Czimber, K., FüHrer, E., GÁlos, B., GribovszKi, Z., Illés, G., HirKA, A., Somogyi, Z., 2018. Sustainability of forest cover under climate change on the temperate-continental xeric limits. Forests, 9: 489.

McManus, M., CsóKa, Gy., 2007. History and impact of gypsy moth in North America and comparison to the recent outbreaks in Europe. Acta Silvatica et Lignaria Hungarica, 3: 47-64.

Mertelík, J., LišKa, J., 2020. Faunistic records from the Czech Republic - Hemiptera: Heteroptera: Tingidae. Klapalekiana, $56(1-2)$. In press.

MitChELL, P.L., 2004. Heteroptera as vectors of plant pathogens. Neotropical Entomology, 33 (5): 519-545.

Mitchell, R.J., Bellamy, P.E., Ellis, C.J., Hewison, R.L., Hodgetts, N.G., Iason, G.R., Littlewoode N.A., Neweya S., Stockana J.A., TaYlor, A.F.S., 2019. Collapsing foundations: the ecology of the British oak, implications of its decline and mitigation options. Biological Conservation, 233: 316-327.

Mutun, S., 2003. First report of the oak lace bug, Corythucha arcuata (Say, 1832) (Heteroptera: Tingidae), from Bolu, Turkey. Israel Journal of Zoology, 49 (4): 323-324.

MuziKA, R.M., LiebHold, A.M., 1999. Changes in radial increment in host and non-host tree species with gypsy 
moth defoliation. Canadian Journal of Forest Research, 29: 1365-1373.

Neimorovets, V.V., Shchurov, V.I., Bondarenko, A.S., Skvortsov, M.M, Konstantinov, F.V., 2017. First documented outbreak and new data on the distribution of Corythucha arcuata (Say, 1832) (Hemiptera: Tingidae) in Russia. Acta Zoologica Bulgarica, 69 (9): 139-142.

Nikolić, N., Pilipović, A., Drekić, M., Kojić, D., PoljakovićPajnik, L., Orlović, S., Arsenov, D., 2019. Physiological responses of pedunculate oak (Quercus robur L.) to Corythucha arcuata (Say, 1832) attack. Archives of Biological Sciences, 71: 167-176.

Paulin, M., Hirka, A., Mikó, Á., Tenorio-Baigorria, I., Eötvös, Cs., GÁspár, Cs., CsóKA, Gy., 2019. Tölgycsipkéspoloska - Helyzetjelentés 2019 őszén [The oak-lace bug - status report in autumn 2019]. In Alföldi Erdökért Egyesület Kutatói Nap. Tudományos eredmények a gyakorlatban. Lakitelek 2019. Kecskemét, Alföldi Erdőkért Egyesület, p. 110-119.

Paulin, M., Hirka, A., Mikó Á., Tenorio-Baigorria I., Eötvös, Cs., Gáspár, Cs., CsóKA, Gy., 2020. A tölgycsipkéspoloska Magyarországon - helyzetkép 2019 őszén [The oak-lace bug in Hungary - situation in the autumn of 2019]. Növényvédelem, 81 [N. S. 56] (6):245-250.

Puttler, B., Bailey, W.C., Triapitsyn, S.V., 2014. Notes on distribution, host associations, and bionomics of Erythmelus klopomor Triapitsyn (Hymenoptera, Mymaridae), an egg parasitoid of lace bugs in Missouri, USA, with particular reference to its primary host Corythucha arcuata (Say) (Hemiptera, Tingidae). Journal of Entomological and Acarological Research, 46: 30-34.

Roques, A., 2010. Taxonomy, time and geographic patterns. Chapter 2. In Roques, A., Kenis, M., Lees, D., Lopez, C., VaAmonde, W., Rabitsch, Y-V., Roy, D.B. (eds). Alien terrestrial arthropods of Europe. Vol. 1. BioRisk, 4. Sofia: Pensoft, p. 11-26.

Sallmannshofer, M., Ette, S., Hinterstoisser, W., Cech, T. L. Носн, G., 2019. Erstnachweis der Eichennetzwanze, Corythucha arcuata, in Österreich [First record of the oak lace bug, Corythucha arcuata, in Austria]. Forstschutz Aktuell, 66: 1-6.

SAVVIDIS, G., Zartaloudis, Z., VAFEAs, G., 2009. Massive fish losses in rainbow trout cultures of Louros River (NW Greece) after strong summer rainfall. Implication of the sycamore lace bug Corythucha ciliata (Hemiptera: Tingidae). Bulletin of the European Association of Fish Pathologists, 29 (2): 66-72.
Smith, R.M., BAKer, R.H.A., Collins, D.W., KorycinSKa, A., Malumphy, C.P., Ostojá-Starzewski, J.C., Prior, T., Pye, D., ReID, S., 2018. Recent trends in non-native, invertebrate, plant pest establishments in Great Britain, accounting for time lags in reporting. Agricultural and Forest Entomology, 20: 496-504.

Sönmez, E., Demirbag, Z., Demir, I., 2016. Pathogenicity of selected entomopathogenic fungal isolates against the oak lace bug, Corythucha arcuata Say. (Hemiptera: Tingidae), under controlled conditions. Turkish Journal of Agriculture and Forestry, 40: 715-722.

Streito, J.C., Balmès, V., Aversenq, P., Weill, P., ChaPIn, E., Clément, M. Piednoir, F., 2018. Corythucha arcuata (Say, 1832) et Stephanitis lauri Rietschel, 2014, deux espèces invasives nouvelles pour la faune de France (Hemiptera, Tingidae) [Corythucha arcuata (Say, 1832) and Stephanitis lauri Rietschel, 2014, two new invasive species for the fauna of France (Hemiptera, Tingidae)]. L'Entomologiste, 74: 133-136.

SzŐNYI, L., 1962. Adatok néhány fafaj vastagsági növekedéséhez [Data on the increase in thickness of some tree species]. Az Erdö, 97 (7): 289-300.

Tuba, K., HoRváth, B., LaKaTos, F., 2012. Inváziós rovarok fás növényeken [Invasive insects on woody plants]. Sopron: Nyugat-magyarországi Egyetem Erdőmérnöki Kar. $120 \mathrm{p}$.

Wheeler, A.G., Benjamin, J.R., Stinner, R., Henry, T.J., 1975. Biology and nymphal stages of Deraeocoris nebulosus (Hemiptera: Miridae), a predator of arthropod pests on ornamentals. Annals of the Entomological Society of America, 68 (8): 1063-1068.

ZieliŃSKA, A., LIS, B., 2020. Ocena możliwości potencjalnej ekspansji prześwietlika dębowego Corythucha arcuata (Say, 1832), inwazyjnego gatunku z rodziny Tingidae (Hemiptera: Heteroptera), na tereny Polski [Evaluation of the possibilities of potential expansion of the oak lace bug Corythucha arcuata (Say, 1832), an invasive species of Tingidae (Hemiptera: Heteroptera), into the territory of Poland]. Heteroptera Poloniae - Acta Faunistica, 14: $175-180$.

Zúbrik, M., Gubka, A., Rell, S., Kunca, A., Vakula, J., Galko, J., Nikolov, Ch., Leontovyč, R., 2019. First record of Corythucha arcuata in Slovakia. Short communication. Plant Protection Science, 55: 129-133.

Received August 9, 2020 Accepted September 29, 2020 